\title{
Between Exoticization and Marginalization. Current Problems of Gypsy Studies
}

\section{Elena Marushiakova and Veselin Popov}

\begin{abstract}
:
The article presents different approaches and methodological problems that appear in the study of Gypsies who live in Eastern Europe, or of Eastern European Origin. Two basic paradigms of studying gypsies are discussed - their exoticization and their marginalisation. Studies of the Gypsies as well as their reception in social practice and policies can take on features of one or both of these two paradigms.
\end{abstract}

Keywords: Gypsies; Roma; marginalisation; exoticization; anthropology; ethnology; Romani Studies
Elena Marushiakova and Vesselin Popov have published a number of studies on Gypsies in Bulgaria, the Balkans and Central and Eastern Europe. Their major works include the first monograph on the history, ethnography, social structure and culture of the Gypsies in Bulgaria (1997), a book on Gypsies in Ottoman Empire (2000) and a book on Gypsies on the Black Sea area (2008). They are the editors of a publication series in the field of Romani Studies ('Studii Romani'). Dr. Elena Marushiakova is holder of the Fulbright New Century Scholars Award from the Bureau of Educational and Cultural Affairs of the U.S. Department of State and the Council for International Exchange of Scholars. She is head of the Department of Balkan Ethnology at the Institute of Ethnology and Folklore Studies with Ethnographic Museum, Bulgarian Academy of Sciences, where together with Dr. Vesselin Popov they created a specialised Romani/Gypsy Studies Library with an Archive and the Romani Studies Centre, chaired by Vesselin Popov.

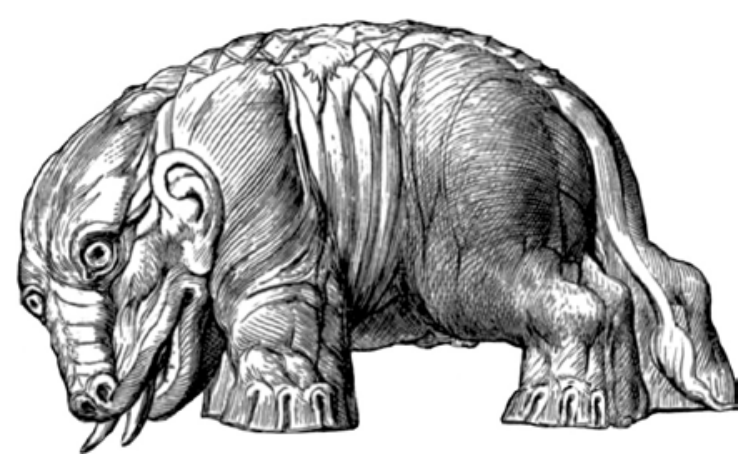


When writing about Gypsies from an Eastern European perspective, it is necessary to start with two terminological specifications. Firstly, by "Eastern Europe" we mean the whole region of Central, Eastern and South-Eastern Europe, encompassing the countries to the East of the so-called 'iron curtain' that divided Europe after World War II, and where we have carried out field work over the course of the past three decades. Secondly, we do not use "Gypsies" as the term is accepted in the English-speaking world (including in the scholarly jargon) to signify nomad communities regardless of their ethnic origins and identity. For us, Gypsies definitely are not communities characterised exclusively by their way of life. We are using the term in the meaning implied in the entire region of Eastern Europe: as a name of a clearly defined and distinctive ethnic community (called in various countries by similar names - 'Cigáni', 'Cikáni', 'Cyganie', 'Čigonai', 'Čigāni', 'Cigany', 'Ţigani', 'Çingeneler', Zigeuner, 'AӨıүүavoı', 'Цигани', 'Цыгане', etc.), whose ancestors had migrated from the Indian subcontinent to Europe more than a millennium ago.

The question "Who are the Gypsies?" (or expressed in a more politically correct manner "Who are the Roma?") that was posed during a notorious survey on poverty in post-socialist societies, led by the famous American sociologist of Hungarian origin Ivan Szelenyi (Emigh/ Szelenyi 2000; Szelenyi 2001), is meaningless for Eastern Europe. In the public discourse of the entire region a clear idea of Gypsies as a separate, clearly defined ethnic community with common origins has existed for centuries, i.e. everyone knows here "who the Gypsies are". Therefore problems in this respect can only arise from the identification of certain individuals, outside the social environment in which they were born and bred, but not in regard to the community/communities on the whole. In Eastern Europe the Gypsies, similarly to any other community of that kind, are considered only in primordial terms, and in an ethnic discourse (as any other ethnic community). In other words, one is born a Gypsy, one cannot become a Gypsy, and one remains a Gypsy for life (as do one's ancestors). It is unthinkable that an entire book dedicated to the question "Who are the Gypsies?" could appear in Eastern Europe, and also one which states from its first pages that this is a question that does not have an answer (Mayall 2004), because here this perspective is irrelevant, incomprehensible and therefore meaningless.

The Gypsies of Eastern Europe (as well as any of the peoples inhabiting this territory) consider themselves and are referred to by "others" in a largely ethnic discourse. The reasons for this lie in the fact that the ideas of constructivism and civil nation in Eastern Europe in the prevailing majority of cases have been reduced to the concept of the nation-state, which in practice considers itself mainly 
as an ethno-nation (after the breakdown of Yugoslavia and USSR, the Russian Federation is the only exception in this regard). That is why the newly created nation-states (from the $19^{\text {th }}$ century to date) turn their gaze primarily to the past, and initiate a process of an active involvement of this past in the national-historical mythology. In this part of the world in a considerably higher degree than elsewhere, history is not just a science, but rather a part of that national mythology. There, even to this day every nation resurrects and projects into the contemporary world its own version of the "glorious past". In the individual countries the process of creating the new ethno-national community, following a civil-nation state-building model, adopts in the end a primordialist format.

In the general social and political context of Eastern Europe, Gypsies can be considered (as any other nation in the region) an "imagined community" (Anderson 1991), but unlike the other nations, it has been "imagined" not by its own members, but by the rest of the population that has been living alongside for centuries. Thus it turns out, somewhat paradoxically, that the boundaries of this community in the sense of Frederic Barth (Barth 1969) are determined in fact not by its members, but by the surrounding populations, regardless of the self-perception of the Gypsies and their identity (or at least the one they would like to demonstrate in public), and they will always be perceived (and treated, respectively, in various life situations) as nothing other than "Gypsies".

The question whether Gypsies could be regarded as one entire community on a global scale, or rather as separate Gypsy communities whose mother tongues are not only various dialects of the Romanes, but also Armenian, Arabic, Turkish, Greek, Albanian, Romanian, Hungarian, Ukrainian, Spanish, etc. (Fraser 1992; Marushiakova/ Popov 2001, 33-53; Kenrick 2004), remains arbitrary to many authors to this date. It is not uncommon (not only in Eastern Europe, but elsewhere in the world, too) to have communities considered as Gypsies by the surrounding population who have nevertheless chosen an identity "other" than the Gypsy one- they reveal a so-called "preferred ethnic identity", i.e. an identity that is publicly declared or really experienced, or even actively constructed (Marushiakova et al. 2001). In many cases there may be an absence not only of an awareness of the unity of the Gypsy/ Roma community (or it may exist only on particular identity levels), but sometimes there may be an absence of any knowledge of the existence of any other subdivisions of this community, as the case of the small group of Iranian Zargari (Marushiakova/ Popov 2010).

Over the course of the past few years, most Eastern European countries have taken on politically correct terminology by introducing the term "Roma” (or Romove, Romowie, Роми, Ромалы, etc.). 
The terminological change implies a change of attitudes. The result however is that the new appellation "Roma" can be found only in "official" public speech of certain public entities - state and local governments, political parties, third sector, media and others. As a whole, it has not had a real impact on public consciousness, i.e. within the majority society they continue to be identified namely as one community, as "The Gypsies". Accordingly, the attitude towards them of the macro society is (and always has been) as towards "Gypsies" and policies and projects targeting them, respectively, were (and are) placed under this common denominator. In our article we will use the designation "Gypsies" because we are studying the actually existing social relations. This is because we are being scientific about our study by examining "what is" (no matter how designated) and not "what should be" (independently of what for whatever reasons or criteria shall be considered "correct" or even less what is considered as "politically correct").

First we have to take into consideration the fact that the Gypsies are not a hermetically isolated and self-sufficient social and cultural system. Gypsies have always existed at least in 'two dimensions', or in two coordinate plans - both as a separate community and as a society (in particular as its ethnically-based integral part within the respective nation-state). The latter case starts from a fundamental principle based on the juxtaposition community - society (Gemeinschaft - Gesellschaft), proposed as early as the end of the $19^{\text {th }}$ century (Tönnies 1887). This distinction is used in our case, however, not in the meaning as initially implied by its author, but with altered content cleared from its evolutionary hierarchy as relations between two simultaneously existing typological phenomena intertwined in one inseparable unity.

The failure to comprehend the essence of the "community-society" distinction and interconnection results in incorporating the Gypsies within the frames of two basic paradigms, which can be summed up as marginalization (as a social layer of the society), and exoticization (as a separate community).

When the Gypsies are seen primarily as part of the respective social structure, they are mostly referred in terms of marginalization, usually of social and economic kinds. When the Gypsies are primarily seen as a community, and when the general cultural context and their social dimensions are ignored, it appears that they are being exoticized. Paradoxical as it may sound, it is not uncommon that the latter two approaches which at first glance look opposed to each other can in fact complement each other, in particular when discussing specific policies and projects of govern- 
mental and public structures, and/ or civil society organisations on various levels. And what is more important in our case, these two major paradigms are presented in academic research as well, they actually predetermine also the researchers' approach towards the Gypsies and accordingly also predestine the investigations' outcomes and their scientific interpretation.

A common phenomenon is the ultimate dependence and interconnection of the scientific approach (and respectively of the research results) with 'external' factors external to science (in our case of major socio-ideological paradigms). Science is not and cannot be an island of "pure objective knowledge", it always develops according to the general socio-ideological context and always, at least to some extent, depends on it.

In this article, we will make an attempt to present some major problems (with no claims of completeness) arising from essentially two socio-ideological paradigms within which the Gypsies have been placed in the last circa 20 years of transition in Eastern Europe. Certainly, all countries in this region and their Gypsy communities are unique and have specific characteristics, but there are enough common features and models (both from the point of view of academic knowledge and government and NGO policies, programmes and projects), which enable us to examine the problem in a general and generalizing way.

\section{The Gypsies as a Marginal Community}

The Gypsies are undoubtedly an important segment of the population of Eastern Europe. Hardly anyone could doubt that the social problems of the Roma have deepened and intensified during the so-called time of transition, i.e. the time of social and economic transformation during the 90 s of the $20^{\text {th }}$ century and the beginning of the $21^{\text {st }}$ century. All over the region, old and wellknown factors that have been at play in the past were intensified by major new factors of various kinds, some of which are "external" (i.e. resulting from various structures external to the region and its countries including international institutions, NGOs, donor organizations, and recently also from the euro-bureaucratic machine from Brussels). In the past 20 years, the "Roma issue" has become very fashionable for the implementation of various projects at the level of government policies, NGOs or academic research. All three areas are mutually interrelated and overlap. This is understandable considering the magnitude of the infl in all three areas of identical social 
and ideological paradigms. The paradigm in this case is leading to their perception as marginalised community.

In the difficult period of transition the "Roma issue" and the Gypsies' problems have been translated into theidea of the social inequality of the Roma community as such. A great number of projects managed by NGOs have been implemented to overcome this inequality, later followed by national programmes and then also by European Union project lines. Roma activists from Eastern Europe united in political parties and/ or NGOs were however not able in the end to control or at least steer the basic tendencies in the development of key concepts and the ensuing projects and programmes. This is the reason for the growing dissatisfaction with results of these top-down policies, or rather, for the lack of results. More and more, Roma activists speak about a "Gypsy industry" that subsists on the basis of stating Roma problems and which by implication does nothing towards solving these problems, because it would lose its source of income.

The leading concept of this approach is that Gypsies should not betreated as a "normal community" with its own identity and ethnic culture, but as a strongly marginalised and to a great extent anomic community that needs constant special care and social patronage. This approach is not an original creation of the "Gypsy industry", it was rather the base of almost all state policies for "integration" of Gypsy communities worldwide. These policies are characterised almost entirely by a lack of any positive results. Usually the "New Time" is opposed to the previous era, or in other words "the Time of Democracy" is opposed to the so-called "Time of Communism", but in terms of governmental policies towards the Gypsies thereis clear succession and continuity. During the second half of the $20^{\text {th }}$ century, in the so-called "communist countries" in the region, there was one principal and identical political line in spite of the various differences between the individual countries characterized by an effort to integrate the Gypsies into society. The individual countries more or less openly acknowledged such social integration as the first step on the way to ethnic assimilation of the Gypsies.

When analyzing the national programmes and strategies targeting Gypsies in individual communist countries, one cannot help noticing that they were essentially identical (Gronemeyer 1983: 43-183; Szabo 1991; J urová 1993; J urová 1996; Crowe 1996; Marushiakova/ Popov 1997; Achim 1998; Lysá 1999; Guy 2001; Marushiakova/ Popov 2007: 125- 156). Indicative is the fact that the national Roma programmes or strategies created in the period of transition are also similar to each other. And they show similarity not only between themselves, which is more or less intelligible, 
but more striking is the fact they are similar also to the programmes approved and implemented in the previous period. Of course, there is a major difference in terms of ideological reasoning and phraseology, but apart from that, we see to a large extent identical or at least remarkably similar activities meant to resolve specific problems in the fields of employment, housing, schooling and education, health, including the problems of Roma women (which are also one of the recent "hits"). Thus, the activities planned and put into practice nowadays as well as the projects directed to the overcoming of Roma problems (including the new European programmes and projects) are well known from the recent past and that is why their outcomes can easily be anticipated.

Since the break-down of the "Eastern bloc", academic research in the majority of cases continues to serve the general social and ideological paradigms. In the past circa twenty years, dozens or even hundreds of mostly (but not only) sociological studies have been published (if we take the region as a whole) that focus on the social and economic problems of the Gypsies or to be more precise on the marginalised segments of Gypsy society (Tomova 1995; Jakšić/Bašić 2005; Ringold 2000; Ringold et al. 2005; Lysá 1999; UNDP 2003; UNDP 2005; Vašečka 2002; Zamfir/ Zamfir 1993; Zoon 2001a; Zoon 2001b). We believe that it is not necessary to go into details and to interpret the interests of institutions commissioning these studies (World Bank, UNDP, the Open Society Foundations network, etc.). They aim at justifying the need for future projects and activities and bring results that are expected, i.e. results that are called for. In order to express this more directly, let us refer to a Balkan Gypsy proverb, which could be translated almost literally with an old English proverb: "He who pays the piper calls the tune". It cannot be expected that big donors like the World Bank, UNDP or the Network of "Open society" foundations whose primary mission and reason for their existence is to overcome Gypsy problems will support research and publications whose findings are contrary to this fundamental mission. So today there are dozens of sponsored publications on huge housing problems of the Gypsies, and only three books are on so-called "Gypsy palaces" concerning Gypsies who do not have any housing problems (Calzi et al. 2007; Gräf 2007; Andresoiu/ Ciocazanu 2008).

A series of very similar sociological studies in terms of approach and results have been published over the course of the past 20 years, some of them devoted to Gypsies in various countries in Eastern Europe and others that summarise developments throughout this region. Indeed these studies and surveys are used as scholarly background needed for further development of this niche project (concerning the Gypsies and their problems) and de-facto they confirm and legalise the patronising role of the "Gypsy 
industry". Moreover, there is also a succession within scientific studies of similar type, characteristic for a previous historical era, in which the socio-economic problems of Gypsies are also highlighted and ways to overcome them are looked for. Especially significant in this regard is the case of the famous sociologist Istvan Kemenyi, one of the fathers of modern sociology in Hungary and long-term president of the Hungarian Sociological Association whose works in the field of Gypsy studies done in time of socialism, were and continue to be considered a classic reference (Kemeny 1992).

Additionally, in the last two decades, the study of Gypsies from Eastern Europe has seen a new scientific discipline emerge. It can hardly be defined in disciplinary and methodological terms, since it is a particular type of research that we call "the NGO-science". Its representatives may have different academic backgrounds, but often have none (including cases where the only qualification of the authors of this direction is their Roma origin and their mastery of English). Their methodology, formally speaking, is interdisciplinary (including law, sociology, political science, etc.), but it is often incorrectly applied in terms of data collection and therefore the results are hardly verifiable, and usually with tendentious conclusions.

Furthermore, the inclusion of Gypsies as co-authors of NGO-sector publications (with claims to be scientific research) is a symptom of the de-facto public recognition of the right of Gypsies to be researchers (or "experts" according to the aocepted NGO terminology) only by virtue of their origin and not according to their qualification. That approach is indeed an introduction into Eastern European academic research of Gypsies of the principles from the so-called "Native/ Indigenous science”. Native/ Indigenous science is currently an expanding research fi in the U.S., Canada and Australia that arose to describe the local native population, as well as the "aborigines" in Australia. To participatein "native" or "indigenous science", one must have been born into the ethnic groups. This because the object of the study is the ethnic culture from an internal perspective that cannot be aoquired by outsiders.

The opponents of this approach argue that it presupposes the correctness of racist principles, although as a positive classification. It is notable and, or so we would argue, striking that the assumption that inviting representatives of the researched community is a guarantee of scientific quality in Eastern Europe applies only to Gypsies. That is why it is not accidental that some critically thinking Roma activists define this principle as a type of hypocrisy that conceals a hidden or subconscious racism and underestimates highly educated scholars of Roma origin who are working in the field of "regular" and not of "native" science. 
In order to avoid misunderstandings, we would like to stress that we are in no way trying to state that the majority of Gypsy communities do not face major social and economic problems. Such studies often reflect to a certain degree the real and existing problems among Gypsies, but there are also studies that are dubious from a methodological point of view (especially if regard to selection of respondents, use of official statistics, etc.). However, the key problem lies elsewhere in the real and present danger that the whole will be confused with its part, i.e. that the entire ethnic community will be viewed and identified only with its problematic section and as a result, Gypsies will no longer be considered and accepted as a distinct ethnic community with its specific ethnic culture. The famous Czech Roma activist from Ivan Veselý said in this respect: "It's like someone did a research on the homeless on Wenceslas Square and based his perception of all Czechs on these people".

There are many examples of this. One well-known international study focusing on poverty and ethnicity in Central and Eastern Europe conducted under the leadership of representatives of the Hungarian sociological school contains the recurring ideas and conclusions of the school that we have come to know in the 1970s. The Gypsies are described as a special "underclass" and bearers not of their specific ethnic culture but of the "culture of poverty" (Szelényi 2001; Emigh/ Szelényi 2001). Similar sociological research has been conducted in other countries of the region including Romania, Bulgaria, Poland and the Ukraine. These conclusions are directly related to a newly formed Serbian sociological school that defines Gypsies as an "ethno-class", and some authors (political scientists and even ethnologists) from Western Europe also jointed this formulation (Mitrovic 1990; Mihok 1996; Mihok 1999; Mitrović/Zajić 1998; Đorđević 2003; Boscoboinik/Giordano 2005). It is worth noting that in both cases, the research results more or less follow the controversial and often criticized theory of Western anthropology first proposed by the English anthropologist J udith Okely and developed by her followers. According to this theory, Gypsies are not an ethnic community the ancestors of whom migrated from India, but their origin is based on an agglomerate of various marginal sections of the European population (agglomerate of people who were cast out of society during the industrial revolution) (Okely 1983; Lucassen et al. 1998; Willems 1998). In other words, nowadays we have reached a point on which the policy and policy servicing research in time of communist rule focused - the denial of the ethnic dimensions of the Gypsies, a point that was meant as a first step towards assimilation of Gypsies to "mainstream" culture. 
The inclusion of scientific research on the Gypsies in this key social and ideological paradigm leads also to a less expected, but nevertheless natural result - to the overall shift in scientific values and their social function. A firmly established trend over the past decade has been that the most frequently cited scholarly texts on Easter European Gypsies are actually publications by NGOscience, and their mass distribution including via the internet provides easy access to them. The results that influence student writings most acutely is a clear domination of this type of NGO-sector publications. And what is even more important, this type of "NGO science" appears to be the most important for people who determine policies towards Gypsies. To illustrate this trend, it would be enough to check what titles are cited in various reports by the European Commission and other Euroinstitutions. That is why we should not be surprised by the fact that when the origin of the Gypsies is discussed in this type of publications, an article written by the former Head of the European Roma Rights Centre is quoted as a reference. And the problem here is far from commensurability only in scientific terms (which still is not an inconsequential problem in terms of scientific development), but in the fact that the fundamental policies for solving the problems of the Gypsies at a national and European level are actually elaborated on the basis of "NGO-science".

We will give only one example in this regard: In the last year we were commissioned to write a summarised report on the best practices in policies and projects aimed at Gypsies in EU countries within a project managed by a European human rights organization (Improving 2010). The baseline data for the report were collected by researchers in different countries, all of them representatives of the NGO-sector who selected those policies and projects which they believed to be good and deserved to be transferred across the European Union. We made the synthesis and included in it our policy and project recommendations. But the representatives of European structures deleted most of our recommendations from the fi edition and insisted on including others that according to them were much more promising and worth transferring to the member countries. Thus a good European practice recommended to be multiplied in other countries consisted of a project for taking care of a large Gypsy family (keeping children in school, finding work for parents, supplying medical care, etc.), while the University discipline "Romistika" ("Roma Studies") at Charles University in Prague and the Roma Museum in Brno were not recommended. What will be the fi results of this approach when the question comes to designing and implementation of European policies towards the Gypsies is not difficult to predict. 


\section{The Gypsies as an Exotic Community}

In parallel to the main social paradigm analyzed above, there is another one that at first glance is an antipode of the previous. It is the paradigm very popular in Western (mainly in Anglo- Saxon) anthropology on Gypsies as a community characterized by its uniqueness and unrepeatable peculiarity (in terms of their way of life and in culture). The beginning of this approach takes us back to the early nineteenth century when modern ethnography/ ethnology and also social/cultural anthropology were born, although the cultural and historical regions in which they emerged determined their appearance and content. In Eastern Europe, in the conditions of ethno-national states and mostly under the infl of Herder's ideas on the "Volksgeist", the interest was directed primarily toward the anthropologist's "own" people, own history and ethno-cultural traditions, while in the big colonial Empires (notably Britain) the interest was primarily directed towards the "others", towards exotic peoples living outside metropoles. Even though Gypsies are largely European peoples, the romantic images in the public consciousness enables them to fit into the paradigm of Anglo-Saxon anthropology, and this scientific tradition still maintains its dominance globally.

Imposing this Anglo-Saxon approach on Gypsies in Eastern Europe is inextricably interwoven with the context of changes in this region over the past 20 years. The question of methodology has become a key chain in the struggle to conquer the new research market, newly released from the dominance of Marxist ideology. Existing scientific traditions and achievements in the region were blacked out as a whole, usually by applying the labels "Marxist", "nationalist" or even "racist", and consequently in their place the "new approach" conducted by anthropology had to be imposed. In pursuance of these objectives a number of projects were (and continue to be) implemented; a number of summer schools and postgraduate fellowships were organized, with the ultimate objective to educate and form a new generation of anthropologists who would be free from the legacy of communist past. It is not accidental that at the very first meeting within such a project with significant funds from the EU Marie Curie programme, entitled "Promoting Anthropology in Central and Eastern Europe", the most important tenet for those who wished to become "real" anthropologists was formulated as follows - to avoid contacts with local scholarship in the countries where their research will be done. Particularly in Gypsy studies the results of this approach could not sufficiently justify the money and efforts invested. A generation of scholars emerged in Eastern Europe that is less "Marxist", and that considers it unnec- 
essary to read authors from the recent or distant past. This does not turn them into modern anthropologists, rather, it limits their abilities and the outcomes of their research work. As a matter of fact, in Eastern Europe there appeared only a very limited number of studies written by scholars living in this region that could be considered "real anthropology" according to Western standards. Most common are publications in which the authors declare themselves anthropologists, but they are unable to offer any newideas and concepts, and are even less able to get any impressive results.

The reasons for the lack of such results lie in the fact that in Eastern Europe Gypsies in spite of everything are not perceived by their surrounding population (including local researchers) as "foreign". They could beconsidered "others", the attitude towards them may contain various aspects of negativity (especially strengthened in the years of transition), but nevertheless they were, are and will remain "our own", and they cannot be perceived as strange and exotic community. And indeed, what may be exotic in a community whose traditions and customs are largely repetitive of (or at best contaminated by) those of their surrounding population? Moreover, in many cases Gypsies are preserving and developing the customs and traditions of the surrounding population, for whom they are only historical heritage.

We will give only one example to illustrate the exoticizing approach in anthropological studies. A few years ago one article was published by two American anthropologists who have been investigating US Gypsies whose ancestors had migrated from the Balkans more than three decades previously. With some degree of self-criticism, one of the authors mentioned that she "was a bit chagrined" in discovering that celebration of the Serbian slava (a day of certain saint, considered a patron of given kin) "seemed identical" to the Gypsies' slava (Gropper/ Miller 2001, 99). This confession is in fact a direct result of her focusing her research interest on Gypsies without a minimal interest in the cultural context of their ancestors. There is hardly any researcher of Balkan studies, including US researchers, who do not know the significance of this feast for the Balkan peoples (and in particular for Serbs). Furthermore, the discussion of slava in Balkan studies has been a major topic for several decades at the end of the $19^{\text {th }}$ and first half of the $20^{\text {th }}$ century, when one of the main postulates of the Serb national ideology was "where there is slava, there is a Serb". And it is clear that no serious researcher on the Balkans whatever their academic discipline would address the 'slava' as a Gypsy tradition. The exoticization of the Gypsies is possible only if they are approached as an isolated community without taking into account the societal context. However, Gypsies have always been 
part of the societies in Eastern Europe in which they live. In fact their whole way of life requires social symbiosis as they make their living through filling certain social and economic niches, and naturally cannot be isolated from the general social and cultural context. From this perspective, the possibility of placing Gypsies in the paradigm of exoticism is doomed to failure. Gypsies who have lived for centuries in Eastern Europe have achieved a much higher degree of social integration than their counterparts from Western Europe and the New World and cannot fit the exotic paradigm of Western scholars. Therefore, the most common impression of researchers from the West about Gypsies in these regions is that "these are not true Gypsies", they are "assimilated", etc., and that is why they often impose their own theoretical perspectives on the studied community without any attempt to verify them by field research data or even by neglecting of data which contradict their theory. And while for a researcher from the West it is normal to remain in the frames of Orientalism as defined by Edward Said - not to study a given object, but our own ideas about it, reflected by the object itself (Said 1995), the chance that this will be done by local researchers who still live in these realities in fact appears to be negligible.

The fact that the scholars from Eastern Europe live in the reality they are studying stultifies another basic tenet of anthropology - about the methodology of field research. A firmly established fundament in anthropology since Bronislaw Malinowski has been that that field research must be long term, as the researcher should settle in the field (among the studied community). For us, however, studies during which the researcher lives in one village for months, and then writes about Gypsies in general, have limited validity, namely only for a specific Gypsy community and for the actual settlement. They have no particular value as a summarised research on Gypsies, even within one country, given the heterogeneity of the Roma as a community and the various conditions in the societies in which they live. Through long term settling and research in one given place hundreds and thousands of studies could be made, and some of them will repeat each other in greater or lesser degree, but with almost nothing in common, because of the internal diversity of the Gypsies (as community). These studies will not lead to any new knowledge, and will not give more aggregated or more detailed conclusions about Gypsies. This issue is also connected to another tenet of anthropology - about the anonymizing of the researched place and community. For the scholars living in the region any kind of anonymization is meaningless, since everybody who knows the field could easily discover hidden places and names. Hiding this data creates reasonable doubts about the 
credibility of the conducted research and leads to the suspicion that it is anonymized in order to limit possibilities for verification of information. It is a reasonable fear that anonymizing complemented with self-reflection of the researcher will lead to the death of anthropology as science and to its transformation into a specific genre of fiction.

An interesting issue is the impact of the research on Eastern European Gypsies, conducted by scholars from the West on their local colleagues. In this respect, the situation is seemingly paradoxical, but in fact completely regular. In recent years, several otherwise important studies were published also as a result of their authors' ambitions to open new theoretical horizons. In them we find claims to offer a new perspective concerning Gypsies as such, including Okely's theory concerning the alleged non-Indian origin of Gypsies (Okely 1983), Stewart's concept of "brotherhood" among the Gypsies (Stewart 1997), Lemon's theory of Gypsy identity as a form of "performance" (Lemon 1999) or Streck's definition of Gypsy culture as a "contrasting" one (Streck 2003). We will not enter here in a discussion concerning the scientific soundness and therelevance of these concepts to the real situation, in which we can discover both reasonable elements and misleading generalisations. More important is something else - we see more and more young Western scholars uncritically repeating these ideas as frameworks into which the field-research material should be embedded (regardless of the fact that in some cases the research findings contradict them) (Theodosiou 2004, Ries 2007, Engebrigsten 2007, etc.).

The situation in Eastern Europe is different. Some of the books that offer these new theoretical concepts were translated into various Eastern European languages with the support of various donors (especially the Open Society Network through its special programmes) and they were considered as an absolutely essential methodological basis for the researchers from the region and indeed they are among the most frequently cited titles (especially the works of Michael Stewart). Seen from the perspective of their actual use, it appears that in spite of the obligatory quotation, they are not used in practice- neither as providing theoretical concepts, nor in terms of their conclusions. The explanation for this is quite simple. The main distinction between Western and Eastern scholars can be found in the epistemological approach toward the research - the Western scholars' starting point is a methodological one, in which they try to include the field research materials, while Eastern scholars start from the field and on its basis they analyse and draw their conclusion and sometimes (though not necessarily) their theories. For locals, Western European scholars' type of research remains curious and is not perceived as serious research by those who are familiar with Gypsies and their ethnic culture. 
Transferring this exoticizing paradigm into the sphere of social policy leads to the perception that Gypsies are not to betreated as a community of the samerankas other ethnic communities, but a special approach towards them is required that will preserve and further develop the extremely specifi Gypsy ethnic culture. Comparative analysis of the national programmes that have been recently approved and implemented in Eastern Europe clearly shows that their chief objective and their specific activities do not aim at preserving diversity, but rather at bridging and removing differences between Gypsies and other nationalities in various areas encompassing virtually the entire social life including the legal system, employment, housing, healthcare, education, etc. (i.e. all areas that, at least in contemporary terms, could hardly be considered as part of traditional ethnic culture not only of the Gypsies, but of any other people). The desired social integration on one hand and the importance of preservation of Gypsy ethnic culture on the other are in serious discrepancy, and this becomes apparent in various situations. We will point out only some examples in this regard. The most obvious example involves the process of school desegregation, which has been running or at least envisaged for some years now in various Eastern European countries. As a part of this process, Gypsy children are taken from segregated (on a territorial or other basis) schools and transferred into "mixed" (mainstream) schools. The idea of desegregation was born among Roma activists and its staunchest opponents are non-Gypsy people and representatives of international and national institutions and NGO's who usually argue that Roma children will lose their identity and ethnic culture in the mixed schools. If we further develop this logic, the only chance for Gypsies to survive as a community is a total ghettoization and isolation of the Gypsy settlements. This leads to absurd situations as e.g. in Bulgaria, where in 2003 the Ministry Education adopted the principle of desegregation as the official educational strategy and at the same time the segregated schools have been financed and supported through the frames of EU PHARE funding.

In the frames of this exoticizing paradigm, in the name of preserving "otherness" from the point of view of diversity and uniqueness of Gypsy ethnic culture, the majority of Roma national programmes and many European programmes, as well as projects of the NGO sector are built on the principle of stigmatization, i.e. the segregation of the Gypsy community, as well as on the principle of bridging this separation through mediation by "Roma mediators" in various areas of public life such as education, healthcare, social policy and administration. The Gypsies are assigned to the role of "assistants" (teacher's assistant, policeman's assistant, etc.). We need to emphasize that such an approach is applied exclusively to Gypsies, but not to other ethnic minorities in Eastern Europe. 
Again, the explanation is usually based on the uniqueness and distinctiveness of the Gypsy ethnic culture. According to this approach, theGypsies are so specific that therules that apply to them should be different from the rules that apply to other people. If there are protests against this approach, they come from individual Roma activists in various countries of the region and remain unheard. Much higher is however the strata or the so-called "Roma by profession" who find their professional realization as mediators between their community and various public structures (administrative, educational, health, etc.). Respectively this is a very comfortable approach for public structures, which find the principle of mediation very convenient for them and when solutions of a problem are needed they could be guided by the principle "the Roma themselves should solve the issues".

What are the roots of all these discrepancies? Is it true that the Gypsies do not understand their interests and need "good white brothers" to decide in their stead what is good and bad for them as a whole? Only if we affirm this assumption does it makes sense that the diversity and ethnic uniqueness of the Gypsies is best protected if they are separated in reservations where non-Gypsy people have the opportunity to observe the extraordinary and unique Gypsy ethnic culture and then would go home satisfied, feeling they have done their best to preserve the Roma identity and culture. We are not exaggerating because we all know similar situations involving other ethnic communities in various places of the world.

This raises the question whether it is at all possible for one ethnic community (the Roma in our case) to endure in today's globalized world if they exist only in a form that someone (it is not clear who) designated as traditional, distinctive and typical for them (we will not venture to discuss the fact that all traditions were essentially born as a modernization of things from the past). In this sense, the subject of preservation of ethnic identity and ethno-cultural traditions of the Roma community is meaningful when put into a wider context of general social and cultural processes taking place not only on a national, but also on a global level.

\section{Conclusion}

We presented two sides of the same problem concerning research on Gypsies, whether such studies are conducted in the frames of separate scientific disciplines or as one distinct discipline (which we can call Tsiganology or Romani studies). We believe that the two greatest dangers 
that may jeopardize the development of academic research on Gypsies lie in the extremes, i.e. in approaching the Gypsies only as a marginal group or only as an exotic community. And although it may seem absurd at first, these two fundamentally different approaches to the Gypsies are often mixed together and supplement each other.

We consider that the basic problem is in misunderstanding the distinctiveness of Gypsies as an ethno-social and ethno-cultural phenomenon. The Gypsy case is an excellent example of how one nation can exist in two dimensions - as a distinct ethnic community and also as a section of the society as a whole. Whenever the two dimensions come together or one replaces the other, we arrive at what we have been discussing so far - an approach to one entire ethnic community as a marginal group (if we replace the dimension of the community itself) or as an exotic group (if we do not consider the dimension of their belonging to the society as a whole). Mixing the two dimensions is the major reason for the double approach to the Gypsies implemented in various policies as well as in scholar research.

From here comes theanswer of the question how should Gypsy studies be likeand theanswer is very simpleand unequivocal - like studies of all othernations, with the samemethods and criteriaspecific to theindividual sciencesthat direct theirinterest toward Gypsies. This does notmean that Gypsy/ Romani studies should not exist as separate direction in the science. Studies of the Gypsies however cannot bea monopoly of one or another science, and the common object of the research could bethe base of a new, multidisciplinary approach to them, in which ethnology should beamong the leading ones.

\section{Bibliography}

Achim, V. (1998) Ţiganii în istoria Romăniei. București: Enciclopedica.

Anderson, B. (1991) Imagined communities: Reflections on the origin and spread of nationalism. London: Verso.

Andresoiu, B./ Ciocazanu, A. (eds.) (2008) Kastello. Palate ale romilor din Romania. Palaces of the Roma in Romania. Bucuresti: Igloo.

Barth, F. (1969) Introduction. In: Barth, F. (ed.) Ethnic Groups and Boundaries: The Social Organization of Culture Difference. Bergen/ Oslo/ London: George Allen \& Unwin.

Boscoboinik, A./ Giordano, C. (2005) Roma's Identity and the Political Arena. In: Ethnobarometer. Working Papers, 9: 7- 18. 
Calzi, R./Corno, P./Gianferro, C. (2007) Gypsy Architecture. Stuttgart/London: Edition Axel Menges. Crowe, D. (1996) A History of the Gypsies of Eastern Europeand Russia. NewYork: St. Martin's Griffin. Đorđević, D. (2003) The Roma of Serbia. In: Đorđević, D. (ed.) Roma Religious Culture. Nis: YSSSR \& YURoma Center \& Punta.

Engebrigsten, A. I. (2007) Exploring Gypsyness: Power, Exchange, and Interdependence in a Transylvanian Village. NewYork/ Oxford: Berghahn Books.

Emigh, R. J ./ Szelényi, I. (eds.) (2001) Poverty, Ethnicity and Gender in Eastern Europe During the Market Transition. Westport CT: Greenwood Press.

European Commission (2010) Improving the tools for the social inclusion and non-discrimination of Roma in the EU. Summary and selected projects. Luxembourg: Publications Office of the European Union.

Fraser, A. (1992) The Gypsies. Oxford (UK)/Cambridge (US): Blackwell.

Gräf, R. R. (2007) Zigeunerpaläste. Die Architektur der Roma in Rumänien. Cluj/ Napoca: Academia Românâ.

Gronemeyer, R. (1983) Zigeunerpolitik in sozialistischen Ländern Osteuropas am Beispiel der Länder Ungarn, Tschechoslowakei, Polen. In: Gronemeyer, R. (ed.) Eigensinn und Hilfe. Giessen: Focus, 43- 183.

Gropper, R. G./ Miller, C. (2001) Exploring new worlds in American Romani Studies. Social and cultural attitudes among the American Mačvaja. In: Romani Studies, Ser. 5, 11(2): 81- 110.

Guy, W. (ed.) (2001) Between Past and Future: the Roma of Central and Eastern Europe. Hatfield: University of Hertfordshire Press.

Jakšić, B./Bašić. G. (2005) Umetnost preživljavanja. Gdei kako žive Romi u Srbiji. Beograd: Institut za filosofju i društveni teoriju.

J urová, A. (1993) Vývoj rómskej problematiky na Slovensku po roku 1945. Košice: Goldpress. J urová, A. (1996) Rómska problematika 1945- 1967. Dokumenty. 4 zväzky. Praha: USD.

Kemeny, I. (1992) The Gypsy population in Hungary. In: Kemeny, I. Sociological works. Szeged Replika Books.

Kenrick, D. (2004) A Historical Dicţionary of the Gypsies (Romanies). London: The Scarecrow Press. Lucassen, L./ Willems, W./ Cottaar, A. (1998) Gypsies and Other Itinerant Groups. A Socio-Historical Approach. London and New York: Macmillan \& St. Martin's Press. 
Lemon, A. (1999) Between Two Fires. Gypsy Performance and Romani Memory from Pushkin to Postsocialism. Durham: Duke University Press.

Lysá, H. (ed.) (1999) Romovév České republice (1945- 1998). Praha: Socioklub.

Marushiakova, E./ Popov, V. (1997) Gypsies (Roma) in Bulgaria. Frankfurt/ M.: Peter Lang.

Marushiakova, E./ Popov, V. (2001) Historical and Ethnographic Background. Gypsies, Roma, Sinti. In: Guy, W. (ed.) Between Past and Future: the Roma of Central and Eastern Europe. Hatfield: University of Hertfordshire Press.

Marushiakova, E./ Popov, V. (2007) Zigeunerpolitik und Zigeunerforschung in Bulgarien (19191989). In: Zimmermann, M. (ed.) Zwischen Erziehung und Vernichtung. Zigeunerpolitik und Zigeunerforschung im Europa des 20. J ahrhunderts. Beiträge zur Geschichte der Deutschen Forschungsgemeinschaft, Band 3. Stuttgart: Franz Steiner.

Marushiakova, E./ Popov, V. (2010) Migrations West to East in the Times of the Ottoman. (The Example of a Gypsy/ Roma Group in Modern Iran). In: Anthropology of the Middle East, 5 (1): 93- 99.

Marushiakova, E./ Heuss, H./ Boev, I./Rychlik, J./ Ragaru, N./Zemon, R./ Popov, V./ Friedman, V. (2001) Identity Formation among Minorities in the Balkans: The cases of Roms, Egyptians and Ashkali in Kosovo. Sofia: Minority Studies Society “Studii Romani”.

Mayall, D. (2004) Gypsy Identities 1500- 2000. From Egipcyans and Moon-men to the Ethnic Romany. London: Routledge.

Mihok, B. (1996) Die Situation der Roma im siebenbürgischen Landkreis Mureș und die Entwicklung von Sensibilisierungsmaßnahmen gegenüber der Roma-Minderheit. Köln: Heinrich-BöllStiftung.

Mihok, B. (1999) Vergleichende Studie zur Situation der Minderheiten in Ungarn und Rumänien (1989- 1996) unter besonderer Berücksichtigung der Roma. Frankfurt/ M.: Peter Lang.

Mitrović, A. (1990) Na dnu. Romi na granici siromaštva. Beograd: Naučna kniga.

Mitrović, A./Zajić, G. (1998) Social position of the Roma in Serbia. In: Mitrović, A. (ed.) The Roma in Serbia. Belgrade: Centre for Anti-War Action \& Institute for Criminological and Sociological Research.

Okely, J . (1983) The Traveller-Gypsies. Cambridge: Cambridge University Press.

Ries, J . (2007) Welten Wanderer - Über die kulturelle Souveränität siebenbürgischer Zigeuner und den Einfluß des Pfingstchristentums. Würzburg: Ergon Verlag. 
Ringold, D. (2000) Roma and the Transition in Central and Eastern Europe: Trends and Challenges. Washington DC: World Bank.

Ringold, D./ Orenstein, M. A./Wilkens, E. (2005) Roma in Expanding Europe: Breaking the Poverty Cycle. Washington DC: World Bank \&London: Eurospan.

Said, E. (1995) Orientalism: Western Conceptions of the Orient. Harmondsworth: Penguin.

Stewart, M. (1997) Time of the Gypsies. Boulder CO: Westview Press.

Streck, B. (2003) La cultura del contraste: Sobre diferencia y el sentido de pertencia: El casa de los gitanos. In: Revista deAntropología Social, 12:159- 179.

Szabo, G. (1991) Die Roma in Ungarn. Ein Betrag zur Sozialgeschichte einer Minderheit in Ostund Mitteleuropa. Frankfurt/ M.: Peter Lang.

Szelényi, I. (ed.) (2001) Poverty under Postcommunism. Review of Sociology, 7 (2).

Theodosiou, A. (2004) 'Be-longing' in a 'doubly occupied place': The Parakalamos Gypsy musicians. In: Romani Studies, Series 5, 14(1): 25- 58.

Tönnies, F. (1887) Gemeinschaft und Gesellschaft. Leipzig: Verlag Fuess.

Tomova, I. (1995) The Gypsies in the Transition Period. Sofia: IMIR.

UNDP (2002) The Roma in Central and Eastern Europe: Avoiding the Dependency Trap. The Regional Human Development Report. Bratislava: UNDP.

UNDP (2005) Face of Poverty, Face of Hope. Vulnerability Profiles for Decade of Roma Inclusion countries. Bratislava: UNDP.

Vašečka, M. (ed.) (2002) Čačipen pal o Roma. Súhranná správa o Rómoch na Slovensku. Bratislava: Inštitút pre verejné otazky.

Willems, W. (1998) In Search of the True Gypsy. From Enlightment to Final Solution. London/ Portland (OR): Frank Cass Publ.

Zamfir, E./ Zamfir, C. (1993) Ţiganii între ignorare și îngrijorare. București: Alternative.

Zoon, I. (2001a) On the Margins: Roma and Public Services in Romania, Bulgaria, and Macedonia. New York: Open Society Institute.

Zoon, I. (2001b) On the Margins: Roma and Public Services in Slovakia. New York: Open Society Institute.

Regional, H. (n.d.). Warta Berita terkini dan terbaru hari ini. Retrieved J uly 22, 2017, from http:// www.harianregional.com/ 